\title{
SITE SUITABILITY EVALUATION FOR TOURISM DEVELOPMENT USING GIS AND MULTI-CRITERIA EVALUATION TECHNIQUES. A CASE STUDY OF SLĂNIC MOLDOVA AND TÂRGU OCNA, ROMANIA
}

DOI: http://dx.doi.org/10.18509/GBP.2020.90

UDC: 528.931:004.6]:338.48(498)

\author{
Constantin Roșu ${ }^{1}$ \\ Vasilică-Dănuț Horodnic ${ }^{1}$ \\ Petruț-Ionel Bistricean ${ }^{2}$ \\ Dumitru Mihăilă ${ }^{1}$ \\ ${ }^{1}$ Department of Geography, Faculty of History and Geography, \\ "Ștefan cel Mare" University of Suceava, Romania \\ ${ }^{2}$ Regional Meteorological Centre of Moldova, \\ National Meteorological Administration, Romania
}

\begin{abstract}
The terrain and its resources can be detected, mapped and analyzed using modern digital images and geographic cartography techniques, combined with auxiliary and primary data. The mapping helps to identify the areas in which natural and environmental resources are found and to adopt adequate decisions. This study illustrates the utilization of Geographic Information Systems (GIS) instruments and multiple criteria evaluation techniques (MCE) for selecting terrains suitable for touristic development of Slănic Moldova and Târgu Ocna resorts of Sub-Carpathian area of Romania.

Using the share of each factor, nine criteria maps, the following are identified: (land cover, slope, lithology, aspect, proximity to roads, natural attractiveness sites, anthropogenic attractiveness sites, leisure area and public facilities. These maps of identifiable factors have been rated, at first, based on the opinions of experts, the weight of the influence of the research factor to be later calculated using the technique of pair comparison, this being a method of the analytic hierarchy process (AHP). The map of the final model of terrains with touristic potential was created using a linear combination of factors, each with its specific share, in the superposition extension ArcGIS and presented using the fitness scheme of FAO in four classes: highly suitable, moderately suitable, marginally suitable and not suitable terrains for touristic activities.

Identifying favorable and restrictive areas for touristic activities development represents an useful tool for local and regional planning, for local authorities and for the entire population since it can contribute to the avoidance of environmental conflicts on one hand, while on the other hand contributing to the exploitation of local resources in order to improve the economical level of the community. We do consider that our discoveries can be applied in future touristic development strategies (recreation, health, culture) in researched areas.
\end{abstract}

Keywords: terrain suitability, pair comparison, touristic development, AHP, spatial analysis

\section{INTRODUCTION}

Unused and untapped terrains of spa resorts constitute one of the most important resources in regards to the development and expansion of these resorts. Identifying these terrains 
becomes vital to both the local administrative authorities and tourism investors, especially in the context of a rich natural potential, accessible relief, mineral springs and saline existence, potent air ionization.

Identifying and integrating these terrains into the touristic domain can be realized using modern digital imaging and GIS techniques, combined with analytic hierarchy process (AHP) and multiple criterion evaluation (MCE).

One of the most subservient applications of GIS to be used is mapping and terrain suitability analysis [1],[2],[3],[4]. The analysis of terrain suitability has been applied in various situations, as follows: ecology [5],[6], geological favorability [7], fitness of terrain for agricultural activities [8],[9], landscape evaluation and planning [10], impact on the environment [11], public and private sector facilities [12],[13] and regional planning [14].

Notable results have been obtained in the past using the two methods evaluating terrains of Hanoi city for periurban agriculture [15], and synthetic evaluation of the quality of the ecological environment of Hunan province, China [16] and for evaluating the solar farms locations in the south-east of Spain [17].

The purpose of our analysis resides in identifying the best terrains for touristic activity, the ones studied being the available terrains in the area of research. The characteristics of the terrain are all known in this type of analysis (location, dimension, geological substrate, altitude, slope, degree of vegetation cover etc.). The problem stems from the need to classify these terrains based on their characteristics and to create a hierarchy based on their suitability for touristic activities. We combined the GIS method with AHP, taking into account four factors (biophysical and topographical, road accessibility, attractiveness and accessibility of services and facilities) and nine criteria (land cover, slope, lithology, aspect, proximity to roads, natural attractiveness sites, anthropogenic attractiveness sites, leisure area and public facilities).

The specific objectives of this study are:

- to design and develop a GIS-based land suitability model for development of tourism activities

- to establish the main factors and criteria with influence on tourism land suitability

- to weight and score the selected criteria

- to develop the criteria maps with reclassification suitability

- spatially and statistically assessment of land suitability for tourism activities

\section{MATERIALS AND METHODS}

\section{Study area}

The study area is circumscribed by the junction of the Eastern Carpathians and the Moldavian Sub-Carpathians and it encompasses two touristic resorts: Slănic Moldova $\left(46^{\circ} 12^{\prime} 24^{\prime \prime} \mathrm{N}\right.$ and $\left.26^{\circ} 26^{\prime} 18^{\prime \prime} \mathrm{E}\right)$ and Târgu Ocna (46 $16^{\prime} 48^{\prime \prime} \mathrm{N}$ and $\left.26^{\circ} 37^{\prime} 12^{\prime \prime} \mathrm{E}\right)$. Both cities are located in the south-west of Bacău county and are benefiting from a series of natural factors favoring touristic and balneary activities: medium altitudes of 280 meters (Târgu Ocna) and 450-530 meters (Slănic Moldova), prominent air ionization (800-1300 negative ions $/ \mathrm{cm}^{3}$ ), saline (Tg. Ocna), mineral springs in both resorts (Figure 1).

Slănic Moldova with its 4.198 inhabitants (2011) forms itself from its component localities Cerdac, Cireșoaia and Slănic Moldova (residence), occupying a surface of $114,1 \mathrm{~km}^{2}$. The locality is situated on the valley of Slănic River, at the base of Nemira Mountains. The resort is renowned for its carbonated, bicarbonated, slightly sulphurous, 
chlorinated, sodic, hypertonic, hypotonic and oligomineral water springs. The springs have been discovered in 1801, receiving medals at international exhibitions held at Paris, Vienna, Frankfurt/Main.

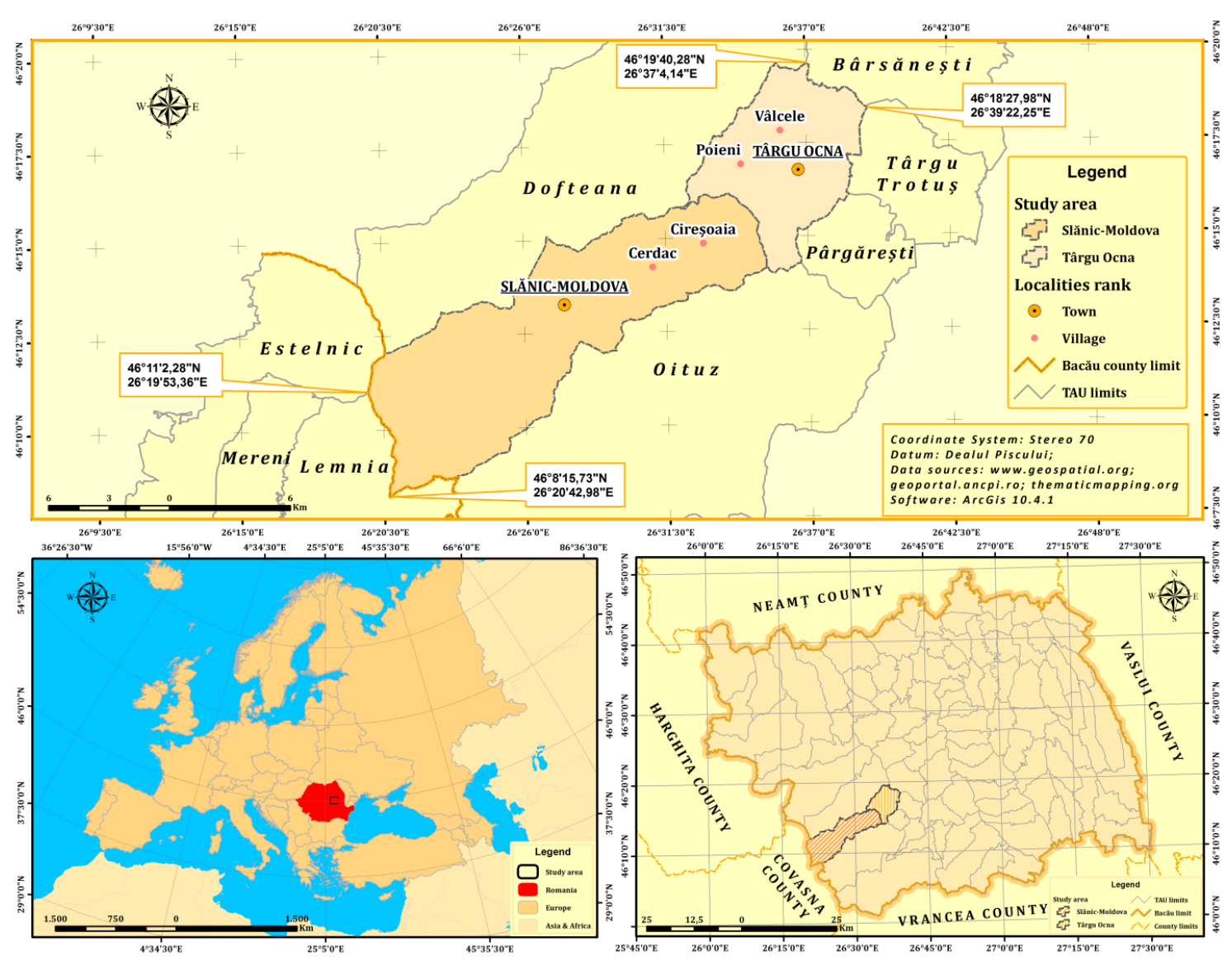

Figure 1. Geographical position of the study area

Târgu Ocna has 11.300 inhabitants (2011) and it occupies $48,9 \mathrm{~km}^{2}$, being formed by the localities Poieni, Târgu Ocna (residence) and Vâlcele. The city is crossed by the valley of Trotus, being sheltered in a Sub-Carpathian depression delimited by Nemira Mountains in south and west, by the Berzunțiu Mountains in north and by Sub-Carpathian hills in north-east. The resort nestles seven mineral springs (sulphurous, chlorinated, sodic, slightly bicarbonated, hypotonic) which have been in use since 1888 . Furthermore, its saline, located in the Trotuş mine at 240 meters depth, has the vastest treatment base in the country.

\section{Data and methods}

\section{Data}

The data used in this study has been collected from a variety of sources, schematically presented in Table 1. The most important data comes from the National Agency for Cadastre and Land Registration, satellite data (Copernicus Land Monitoring Services / CORINE Land Cover 2018), DEM (Digital Elevation Model), geological map of Romania and vector layers extracted from the Open Street Map platform. 
Table 1. Database structure and typology and data sources

\begin{tabular}{|c|c|c|c|c|c|}
\hline No & Database & $\begin{array}{l}\text { Structure } \\
\text { type }\end{array}$ & Attribute & Source/resolution & $\begin{array}{l}\text { Database } \\
\text { type }\end{array}$ \\
\hline 1 & $\begin{array}{l}\text { Administrative } \\
\text { territorial unit }\end{array}$ & $\begin{array}{l}\text { Vector } \\
\text { (polygon) }\end{array}$ & $\begin{array}{l}\text { Territorial } \\
\text { limits }\end{array}$ & $\begin{array}{l}\text { National Agency for } \\
\text { Land Cadastre and Land } \\
\text { Registration }\end{array}$ & primary \\
\hline \multirow[t]{2}{*}{2} & \multirow[t]{2}{*}{ Land cover and use } & $\begin{array}{l}\text { Vector } \\
\text { (polygon) }\end{array}$ & \multirow[t]{2}{*}{$\begin{array}{l}\text { Land cover and } \\
\text { use classes }\end{array}$} & $\begin{array}{l}\text { Copernicus } \\
\text { Monitoring Services / } \\
\text { CORINE Land Cover } \\
2018\end{array}$ & primary \\
\hline & & Raster (grid) & & Conversion $-30 \mathrm{~m}$ & derived \\
\hline 3 & Slope & Raster (grid) & Degrees & DEM - SRTM / 30 m & derived \\
\hline \multirow{2}{*}{4} & \multirow{2}{*}{ Lithology } & $\begin{array}{l}\text { Vector } \\
\text { (polygon) }\end{array}$ & \multirow{2}{*}{$\begin{array}{l}\text { Lithology } \\
\text { classes }\end{array}$} & $\begin{array}{l}\text { Romanian Geological } \\
\text { Institut / 1:200 } 000\end{array}$ & primary \\
\hline & & Raster (grid) & & Conversion $-30 \mathrm{~m}$ & derived \\
\hline 5 & Aspect & Raster (grid) & Orientation & DEM - SRTM / $30 \mathrm{~m}$ & derived \\
\hline 6 & Proximity to roads & $\begin{array}{l}\text { Vector } \\
\text { (polyline) }\end{array}$ & Road category & Open Street Map & primary \\
\hline 7 & $\begin{array}{l}\text { Natural } \\
\text { attractiveness sites }\end{array}$ & Vector (point) & Typology & Open Street Map & primary \\
\hline 8 & $\begin{array}{ll}\begin{array}{l}\text { Historical and } \\
\text { cultural sites }\end{array} & \\
\end{array}$ & Vector (point) & Typology & Open Street Map & primary \\
\hline 9 & Leisure area & $\begin{array}{l}\text { Vector } \\
\text { (polygon) }\end{array}$ & Categories & Open Street Map & primary \\
\hline 10 & Public utilities & Vector (point) & Typology & Open Street Map & primary \\
\hline
\end{tabular}

In order to make a correct assessment of the suitability of the land, we considered the homogenization of the database, as follows: i) use of the same projection system (Stereo70), ii) use of the same spatial resolution $(30 \mathrm{~m})$, iii) applying the same raster format (GRID), iv) using the same number of columns and rows (same spatial extent).

\section{Methods}

Processing the materials, the mapping data and the scientific information has been realized with applications specific to the Geographic Information Systems, ArcGIS 10.4 program and AHP method. The result has been expressed in the form of suitability maps for each criterion. Four steps have been followed in the making of the maps, as follows: i) establishing the four factors and the nine criteria for the analysis, ii) establishing the priority of each factor/criterion, its share and class weight, iii) generating the terrain suitability map for touristic activities, iv) determining the areas with terrains suitable for touristic activities. Details of each step of processing are presented in Figure 2.

In this study, we considered four factors and nine criteria which can help identify the terrains available for touristic activities. The four factors are: (biophysical and topographical, road accessibility, attractiveness and accessibility of services and facilities) and nine criteria (land cover, slope, lithology, aspect, proximity to roads, natural attractiveness sites, anthropogenic attractiveness sites, leisure area and public facilities) 


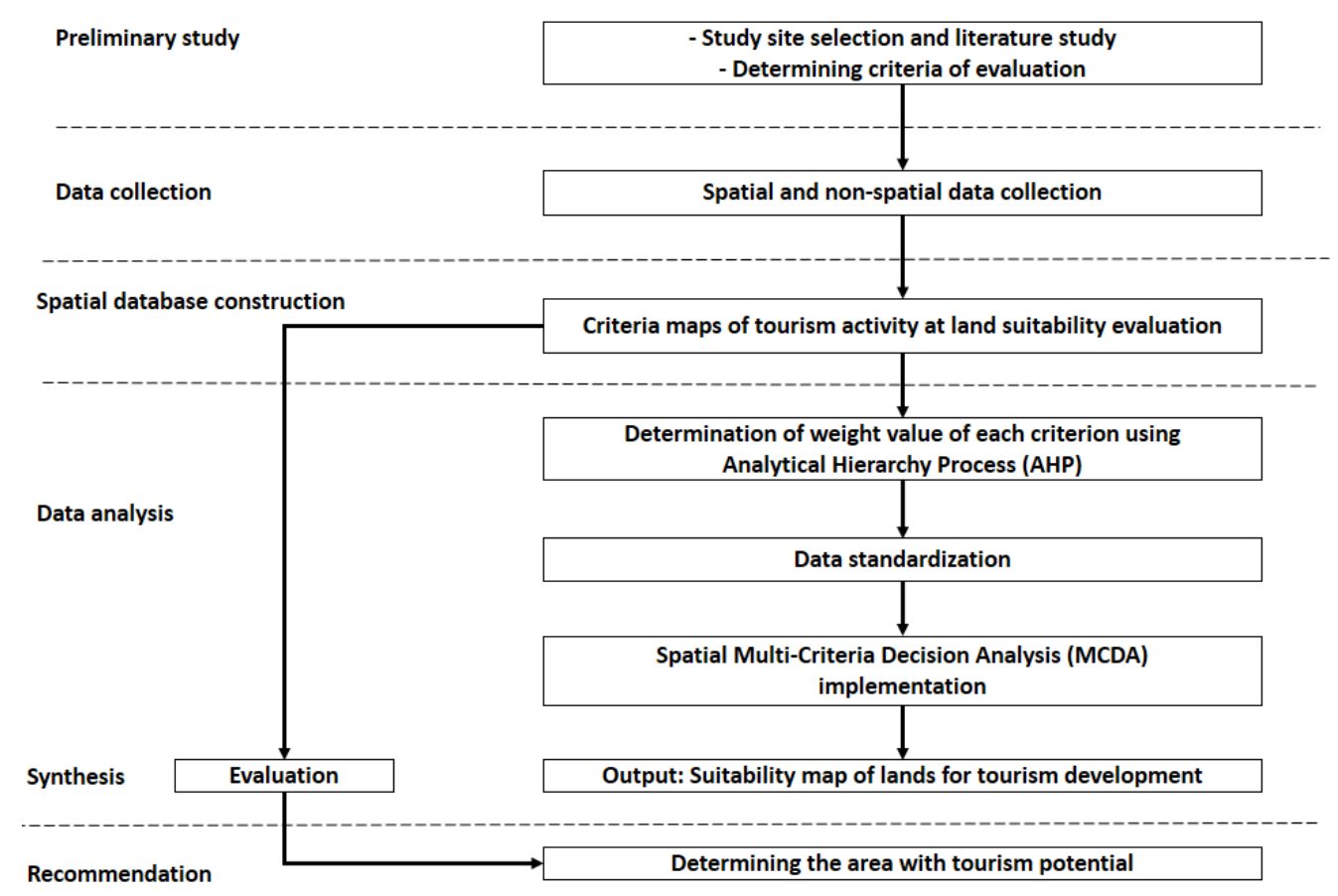

Figure 2. Flowchart of methodological steps [18]

\section{Determination of factors and classification of criteria}

The present study emphasizes the following factors as indicators of suitability according to priorities for developing tourism: biophysical and topographical, road accessibility, attractiveness and accessibility of services and facilities. The assessment of tourism potential was conducted based in the nine criteria, namely: land cover, slope, lithology, aspect, proximity to roads, natural attractiveness sites, anthropic attractiveness sites, leisure area and public facilities. The factors and criteria were chosen according to the experts opinions and information from various thematic sources (Tabel 2).

Tabel 2. Distribution of suitability level for each criteria

\begin{tabular}{|c|c|c|c|c|c|c|}
\hline \multirow{2}{*}{ Factors } & \multirow{2}{*}{ Criteria } & \multirow{2}{*}{ Unit } & \multicolumn{4}{|c|}{ Factor suitability ranking } \\
\hline & & & High & Moderate & Marginal & Not suitable \\
\hline \multirow[t]{4}{*}{$\begin{array}{l}\text { Biophysical } \\
\text { and } \\
\text { topographical }\end{array}$} & Land cover & Classes & $\begin{array}{l}\text { non-irrigated } \\
\text { arable lands, } \\
\text { pastures }\end{array}$ & $\begin{array}{l}\text { complex } \\
\text { cultivation } \\
\text { patterns, } \\
\text { land principally } \\
\text { occupied by } \\
\text { agriculture, }\end{array}$ & $\begin{array}{l}\text { vineyards, } \\
\text { natural } \\
\text { grasslands } \\
\text { transitional } \\
\text { woodland- } \\
\text { shrub }\end{array}$ & $\begin{array}{l}\text { discontinuous } \\
\text { urban fabric, } \\
\text { forests (broad- } \\
\text { leaved, } \\
\text { coniferous and } \\
\text { mixed), } \\
\text { water courses }\end{array}$ \\
\hline & Slope & Degrees & $<15$ & $15-25$ & $25-35$ & $>35$ \\
\hline & Lithology & Classes & flysch & sandstone & gravel, sand & clay, salt \\
\hline & Aspect & Classes & S, SE, SW & $\mathrm{V}, \mathrm{E}$ & NW, NE & $\mathrm{N}$ \\
\hline $\begin{array}{l}\text { Road } \\
\text { accessibility }\end{array}$ & $\begin{array}{l}\text { Proximity to } \\
\text { roads }\end{array}$ & Meters & $<500$ & $500-1000$ & $1000-1500$ & $>1500$ \\
\hline \multirow{3}{*}{ Attractiveness } & $\begin{array}{l}\text { Natural } \\
\text { attractiveness } \\
\text { sites }\end{array}$ & Meters & $<500$ & $500-1000$ & $1000-1500$ & $>1500$ \\
\hline & $\begin{array}{l}\text { Historical } \\
\text { and cultural } \\
\text { sites }\end{array}$ & Meters & $<500$ & $500-1000$ & $1000-1500$ & $>1500$ \\
\hline & Leisure area & Meters & $<500$ & $500-1000$ & $1000-1500$ & $>1500$ \\
\hline $\begin{array}{l}\text { Accessibility } \\
\text { of services } \\
\text { and facilities }\end{array}$ & $\begin{array}{l}\text { Public } \\
\text { utilities }\end{array}$ & Meters & $<500$ & $500-1000$ & $1000-1500$ & $>1500$ \\
\hline
\end{tabular}




\section{Development of criteria maps with reclassification}

The related factors and criteria as seen in Table $\mathbf{2}$ were created and kept as GIS layers in raster grid format. Land cover/use criteria was reclassified from 2018 CORINE land cover map according to the availability for tourism activities. Slope criteria was classified by degree measurement unit. Lithological classes were extracted from Romanian Geological map and were reclassified depending on erosion resistance. Aspect criteria was derived from digital elevation model and was reclassified according to the favorability for activities, the south-east, south and south-west were classified as highest favorable. In combination with lowest values of slope $\left(<3^{\circ}\right)$ was determined the flat area, which was also very favorable for constructions developemnt. Proximity to road network was calculated with Euclidean distance and reclassified according to the nearby roads type (primary, secondaru, tertiary and residential).

We also take into consideration some layers represented as point features (natural and cultural attraciveness sites and public facilities, respectively) against which it was also calculated Euclidean distance and reclassified according to the proximity of this sites. One particular layer was represented by leisure area, which was treated separately, because if it was classified as a land use category it was classified as being unpredictable, being located within the scope of the built space. Secondly, we are interested in the potential to carry out activities around these areas, being identified areas that meet the conditions and the other factors. Depending upon the reclassification nine criteria maps were generated separately (Figure 3).

Analyzing the maps with the nine criteria, several interesting ideas emerge. Therefore, analyzing the map land Cover, it can be observed the vast surface of forest $(71,07 \%)$, only $21 \%$ of terrains being suitable for touristic activities. These are located preponderantly in the north-east of Târgu Ocna.

The Slope Map highlights a relatively high percentage $(60 \%)$ of terrains with a slope included in the high and moderate suitability categories, scattered across the Slănic Valley, more exactly on the left side of the river for Slănic Moldova resort and the northeast of Târgu Ocna resort.

The Lithology Map highlights the vast area of suitability for touristic activities. Only 5\% (clay and salt) of the studied area is not suitable for touristic activities. The majority of this $5 \%$ is located in Târgu Ocna.
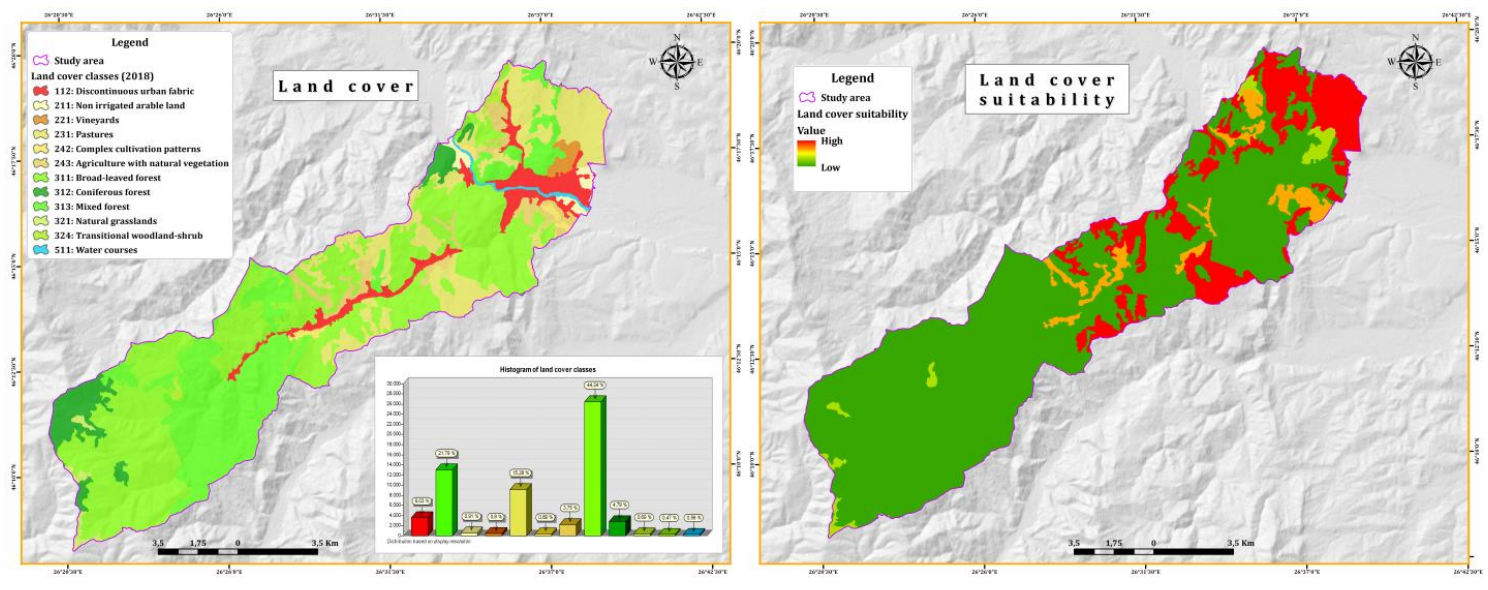


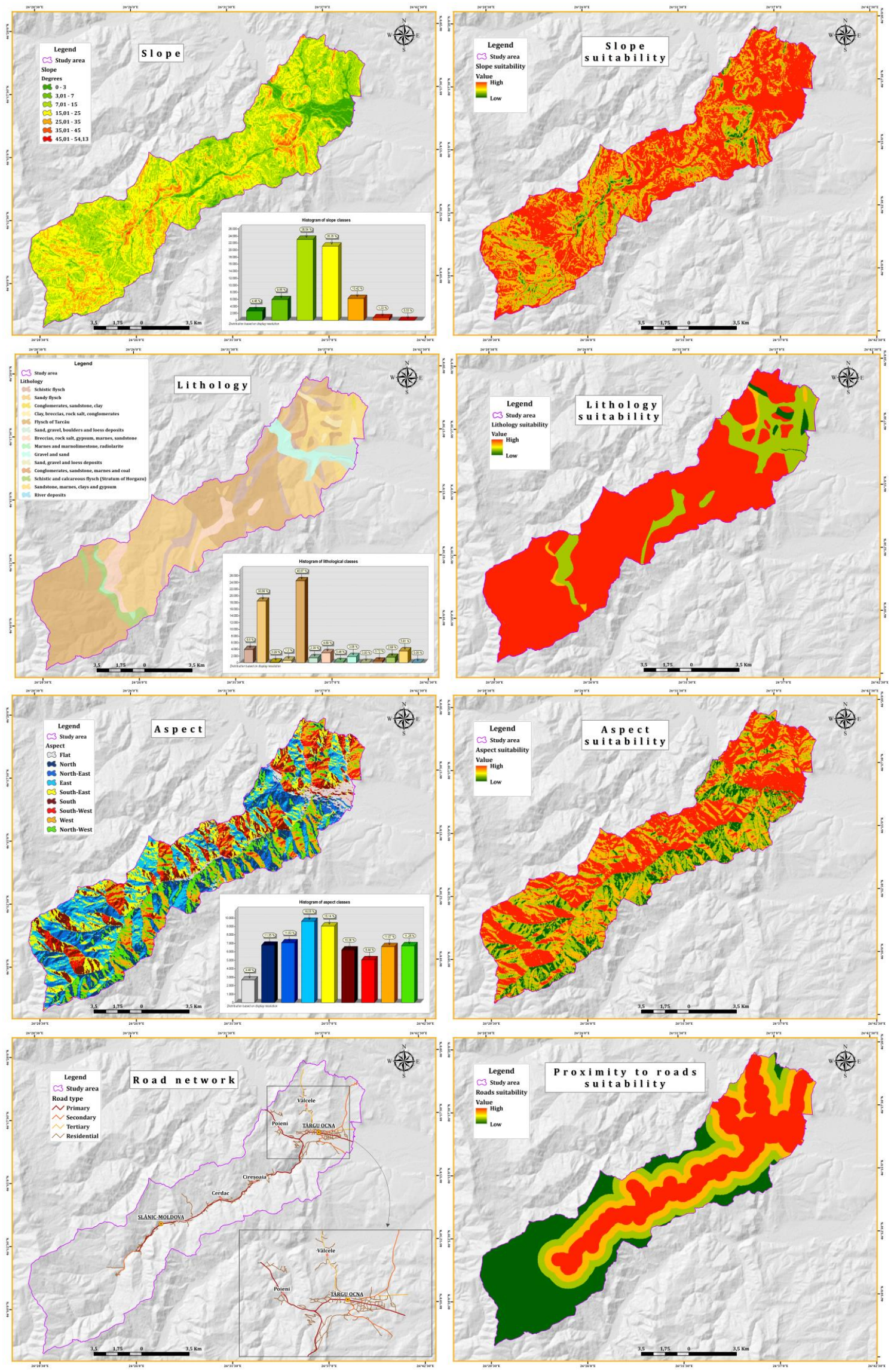




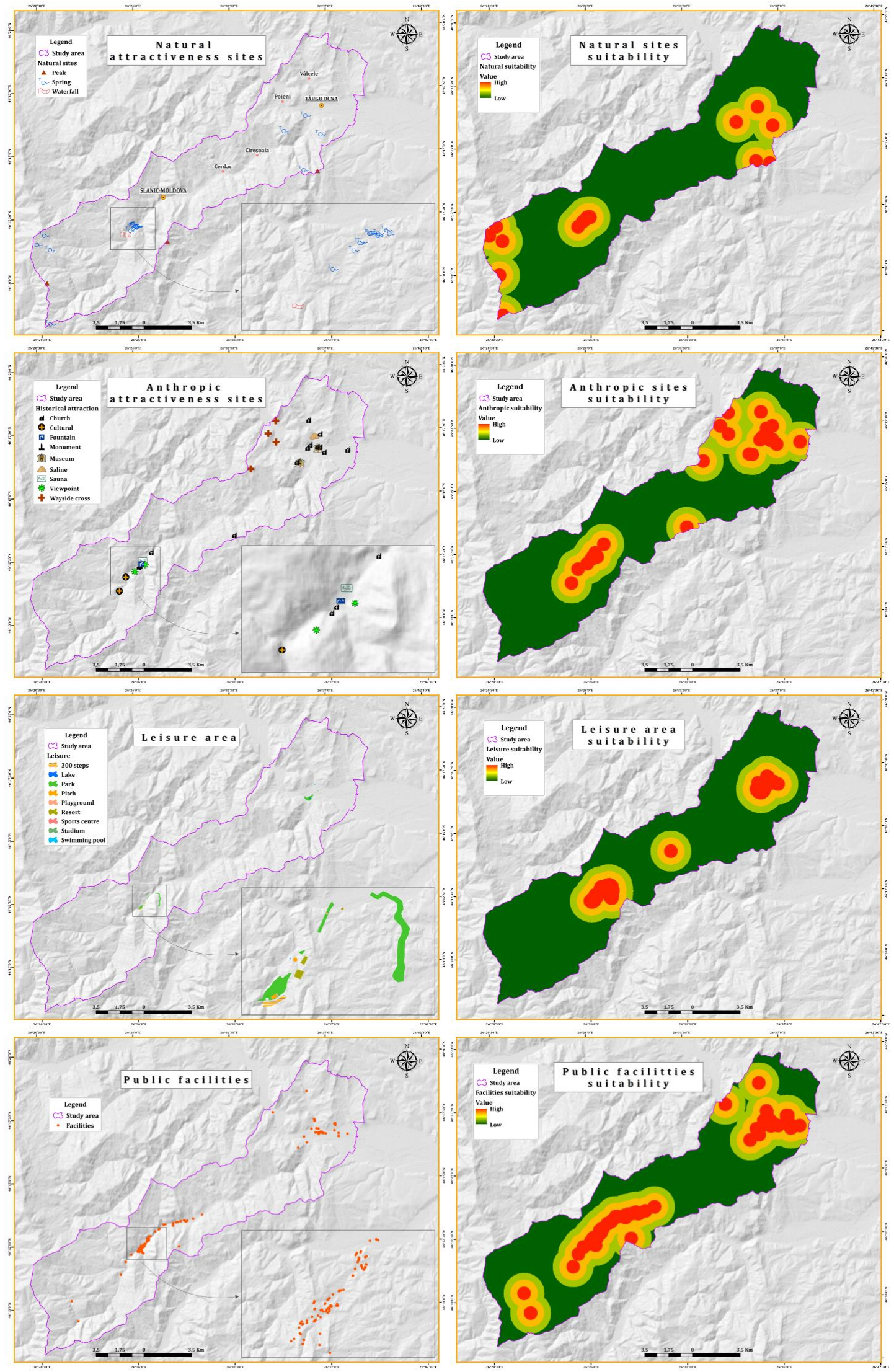

Figure 3. Criteria maps (left) and reclassified maps according to the suitability level (right) 
Judging by Aspect Map, it can be deduced that both resorts have a high degree of suitability (45\%) in the northern, central and western segments of Slănic Moldova, respectively central and northern segments of Târgu Ocna.

The Road Network Map has an axial aspect along the main road crossing Slănic Moldova from north-east to south-west and a radial aspect in Târgu Ocna oriented towards northwest, north and north-east.

The polynuclear aspect can be observed on the maps natural attractiveness sites, anthropic attractiveness sites, leisure area and public facilities for both resorts. Another interesting aspect is represented by the leisure area. This criterion has been interpreted separately, because presenting it as terrain utilization category would have classified it as void of suitability since it is situated in the sphere of constructed space. Furthermore, we are interested in the potential of developing activities around these territories, especially since areas that meet the requirements of the other factors have been identified.

\section{Suitability scoring and development of pairwise comparison matrix}

In order to analyze the suitability, we have assigned a score to each criterion, according to its suitability for the tourism development (Table 3). For this purpose the pairwise comparison matrix using Saaty's nine point weighting scale was applied (Table 4).

Table 3. Nine point weighting scale for pairwise comparison [19]

\begin{tabular}{cc}
\hline Scale & Degree of preference \\
\hline 1 & Equal importance \\
\hline 3 & Moderate importance of one factor over another \\
\hline 5 & Strong or essential importance \\
\hline 7 & Very strong importance \\
\hline 9 & Extreme importance \\
\hline $2,4,6,8$ & Values for inverse comparison \\
\hline
\end{tabular}

In order to develop a pairwise comparison matrix, different criteria are required to generate a ratio matrix These pair wise comparison are taken as input and relative weights are produced as output.

Table 4. Pair wise comparison matrix

\begin{tabular}{lcccccccc}
\hline & $\begin{array}{l}\text { Land } \\
\text { cover }\end{array}$ & Slope & Lithology & Aspect & $\begin{array}{c}\text { Proximity } \\
\text { to roads }\end{array}$ & $\begin{array}{c}\text { Natural } \\
\text { sites }\end{array}$ & $\begin{array}{c}\text { Anthropic } \\
\text { sites }\end{array}$ & $\begin{array}{c}\text { Leisure } \\
\text { area }\end{array}$ \\
$\begin{array}{l}\text { Land } \\
\text { cover }\end{array}$ & 1 & 2 & 3 & 4 & 5 & 6 & 7 & 8 \\
\hline flope & 0.50 & 1 & 2 & 3 & 4 & 5 & 6 & 7 \\
\hline Litholities
\end{tabular}




\section{Computation of the criteria weights}

After the formation of pairwise comparison matrix, we need to derive the criteria weights. This aspect involves the following operations: a) finding the sum of the values in each column of the pairwise comparison matrix (Table 4); b) division of each element in the matrix by its column total; c) computation of average of elements in each row of the normalized matrix, i.e. dividing the sum of normalized scores of each row by the number of criteria (Table 5). These averages provide an estimate of the relative weights of the criteria taken into analysis.

Table 5. Normalized pairwise comparison matrix

\begin{tabular}{lcccccccccc}
\hline & $\begin{array}{c}\text { Land } \\
\text { cover }\end{array}$ & Slope & Lithology & Aspect & $\begin{array}{c}\text { Proximity } \\
\text { to roads }\end{array}$ & $\begin{array}{c}\text { Natural } \\
\text { sites }\end{array}$ & $\begin{array}{c}\text { Anthropi } \\
\text { c sites }\end{array}$ & $\begin{array}{c}\text { Leisure } \\
\text { area }\end{array}$ & $\begin{array}{c}\text { Public } \\
\text { facilities }\end{array}$ & $\begin{array}{c}\text { Criteria } \\
\text { weights }\end{array}$ \\
\hline $\begin{array}{l}\text { Land } \\
\text { cover }\end{array}$ & 0.35 & 0.42 & 0.40 & 0.35 & 0.31 & 0.27 & 0.24 & 0.22 & 0.20 \\
\hline Slope & 0.18 & 0.21 & 0.26 & 0.26 & 0.25 & 0.23 & 0.21 & 0.19 & 0.18 & 0.31 \\
\hline Lithology & 0.12 & 0.11 & 0.13 & 0.17 & 0.18 & 0.18 & 0.17 & 0.16 & 0.16 & 0.15 \\
\hline Aspect & 0.09 & 0.07 & 0.07 & 0.09 & 0.12 & 0.14 & 0.14 & 0.14 & 0.13 & 0.11 \\
\hline $\begin{array}{l}\text { Proximity } \\
\text { to roads }\end{array}$ & 0.07 & 0.05 & 0.04 & 0.04 & 0.06 & 0.09 & 0.10 & 0.11 & 0.11 \\
\hline $\begin{array}{l}\text { Natural } \\
\text { sites }\end{array}$ & 0.06 & 0.04 & 0.03 & 0.03 & 0.03 & 0.05 & 0.07 & 0.08 & 0.09 \\
\hline $\begin{array}{l}\text { Anthropic } \\
\text { sites }\end{array}$ & 0.05 & 0.04 & 0.03 & 0.02 & 0.02 & 0.02 & 0.03 & 0.05 & 0.07 & 0.05 \\
\hline $\begin{array}{l}\text { Leisure } \\
\text { area }\end{array}$ & 0.04 & 0.03 & 0.02 & 0.02 & 0.02 & 0.02 & 0.02 & 0.03 & 0.04 \\
\hline $\begin{array}{l}\text { Public } \\
\text { facilities }\end{array}$ & 0.04 & 0.03 & 0.02 & 0.01 & 0.01 & 0.01 & 0.01 & 0.01 & 0.04 \\
\hline Total & $\mathbf{1 . 0 0}$ & $\mathbf{1 . 0 0}$ & $\mathbf{1 . 0 0}$ & $\mathbf{1 . 0 0}$ & $\mathbf{1 . 0 0}$ & $\mathbf{1 . 0 0}$ & $\mathbf{1 . 0 0}$ & $\mathbf{1 . 0 0}$ & $\mathbf{1 . 0 0}$ & $\mathbf{1 . 0 0}$ \\
\hline
\end{tabular}

\section{Estimation of the Consistency Ratio}

After we have computed the weights for all nine criteria, we need to estimate the inconsistency by Consistency Ratio (CR) checking. CR is generally used to measure how reliable the decisions made relative to several criteria of purely random judgments [20], [21]. For estimating consistency, it involves the following operations:

a) The first step is computation of the weighted sum vector (Table 6). It was done by multiplying weight of matrix comparisons for each of the criteria by the vector of priorities to get a new column vector. Then, the first component of weighted sum vector was divided by the first component of priorities vector to get consistency vector. In this way, all the component of weighted sum vector were divided by the component of priorities vector with the help of the previous Table 5 - Normalized pairwise comparison matrix). Finally, sum up these values over the rows.

Table 6. Computation of consistency vector

\begin{tabular}{clc}
\hline Criteria & \multicolumn{1}{c}{ Weighted sum vector } & $\begin{array}{c}\text { Consistency } \\
\text { vector }\end{array}$ \\
\hline $\begin{array}{c}\text { Land } \\
\text { cover }\end{array}$ & $\begin{array}{l}{[(1 \times 0.31)+(2 \times 0.22)+(3 \times 0.15)+(4 \times 0.11)+(5 \times 0.08)+(6 \times 0.05)+(7 \times 0.04)} \\
+(8 \times 0.02)+(9 \times 0.02)]=2.98\end{array}$ & $2.98 / 0.31=9.71$ \\
\hline Slope & $\begin{array}{l}{[(0.50 \times 0.31)+(1 \times 0.22)+(2 \times 0.15)+(3 \times 0.11)+(4 \times 0.08)+(5 \times 0.05)+(6 \times 0 .} \\
04)+(7 \times 0.02)+(8 \times 0.02)]=2.13\end{array}$ & $2.13 / 0.22=9.78$ \\
\hline \multirow{2}{*}{ Lithology } & $\begin{array}{l}{[(0.33 \times 0.31)+(0.50 \times 0.22)+(1 \times 0.15)+(2 \times 0.11)+(3 \times 0.08)+(4 \times 0.05)+(5} \\
(\mathrm{x} 0.04)+(6 \times 0.02)+(7 \times 0.02)]=1.50\end{array}$ & $1.50 / 0.15=9.72$ \\
\hline Aspect & $\begin{array}{l}{[(0.25 \times 0.31)+(0.33 \times 0.22)+(0.50 \times 0.15)+(1 \times 0.11)+(2 \times 0.08)+(3 \times 0.05)} \\
+(4 \times 0.04)+(5 \times 0.02)+(6 \times 0.02)]=1.04\end{array}$ & $1.04 / 0.11=9.55$ \\
\hline $\begin{array}{c}\text { Proximity } \\
\text { to roads }\end{array}$ & \begin{tabular}{l}
{$[(0.20 \times 0.31)+(0.25 \times 0.22)+(0.33 \times 0.15)+(0.50 \times 0.11)+(1 \times 0.08)+(2 \times 0.0$} \\
\hline
\end{tabular} & $0.71 / 0.08=9.34$ \\
\hline
\end{tabular}




\begin{tabular}{|c|c|c|}
\hline $\begin{array}{c}\text { Natural } \\
\text { sites }\end{array}$ & $\begin{array}{l}{[(0.17 \times 0.31)+(0.20 \times 0.22)+(0.25 \times 0.15)+(0.33 \times 0.11)+(0.50 \times 0.08)+(1 \times} \\
0.05)+(2 \times 0.04)+(3 \times 0.02)+(4 \times 0.02)]=0.49\end{array}$ & $0.49 / 0.05=9.17$ \\
\hline $\begin{array}{l}\text { Anthropi } \\
\text { c sites }\end{array}$ & $\begin{array}{l}{[(0.14 \times 0.31)+(0.17 \times 0.22)+(0.20 \times 0.15)+(0.25 \times 0.11)+(0.33 \times 0.08)+(0 .} \\
50 \times 0.05)+(1 \times 0.04)+(2 \times 0.02)+(3 \times 0.02)]=0.34\end{array}$ & $0.34 / 0.04=9.08$ \\
\hline $\begin{array}{l}\text { Leisure } \\
\text { area }\end{array}$ & $\begin{array}{l}{[(0.13 \times 0.31)+(0.14 \times 0.22)+(0.17 \times 0.15)+(0.20 \times 0.11)+(0.25 \times 0.08)+(0 .} \\
33 \times 0.05)+(0.50 \times 0.04)+(1 \times 0.02)+(2 \times 0.02)]=0.24\end{array}$ & $0.24 / 0, .02=9.10$ \\
\hline $\begin{array}{c}\text { Public } \\
\text { facilities }\end{array}$ & $\begin{array}{l}{[(0.11 \times 0.31)+(0.13 \times 0.22)+(0.14 \times 0.15)+(0.17 \times 0.11)+(0.20 \times 0.08)+(0 .} \\
25 \times 0.05)+(0.33 \times 0.04)+(0.50 \times 0.02)+(1 \times 0.02)]=0.17\end{array}$ & $0.17 / 0.02=9.22$ \\
\hline
\end{tabular}

b) After the calculation of consistency vector, another two terms i.e. lambda (l) and the consistency index (CI) calculations were required to check the inconsistency. The value for lambda computed as the average value of the consistency vector (Table 6). The calculation of CI is based on the observation that $\lambda$ is always greater than or equal to the number of criteria under consideration ( $n$ ) for positive, reciprocal matrices and $\lambda=n$, if the pairwise comparison matrix is consistent matrix. Accordingly, $\lambda$-n can be considered as a measure of the degree of inconsistency.

This measure can be normalized as follows:

$$
\mathrm{CI}=(\lambda \max -\mathrm{n}) /(\mathrm{n}-1)
$$

Calculation of lambda $(\lambda)=(9.71+9.78+9.72+9.55+9.34+9.17+9.08+9.10+9.22 / 9)=9.41$ Condition 1: $\lambda$ should be equal or greater than the number of criteria under consideration. The value calculated above satisfies this condition.

Calculation of consistency index $(\mathrm{CI})$

$$
\mathrm{CI}=(\lambda-\mathrm{n}) /(\mathrm{n}-1)=(9.41-9) /(9-1)=0.051
$$

The term CI, is defined as consistency index. To determine the quality of C.I., AHP compares it by random index (R.I.) and the result is called consistency ratio (C.R.), which can be defined as:

$\mathrm{CR}=\frac{\mathrm{CI}}{\mathrm{RI}}$, where $C I=$ Consistency Index and $R I=$ Random Index

The random index is the consistency index of a randomly generated pairwise comparison matrix of order 1-10 obtained by approximating random indices using a sample size of 500 [22].

Table 7 shows the value of R.I. sorted by the order of matrix. The consistency ratio (CR) is designed in such a way that if CR 0.10 , then the ratio indicates of inconsistent results. In such cases one should review and go through again the original values in the pairwise comparison matrix.

Tabel 7. Random index values

\begin{tabular}{ccccccccccc}
\hline $\mathbf{n}$ & 1 & 2 & 3 & 4 & 5 & 6 & 7 & 8 & 9 & 10 \\
$\mathbf{R I}$ & 0.00 & 0.00 & 0.58 & 0.9 & 1.12 & 1.24 & 1.32 & 1.41 & 1.46 & 1.49 \\
\hline
\end{tabular}

$\mathrm{RI}=$ random inconsistency indices for $\mathrm{n}=10$

Calculation of consistency ratio $(\mathrm{CR}), \mathrm{CR}=\mathrm{CI} / \mathrm{RI}=0.051 / 1.46$ (Since $\mathrm{RI}=1.46$ for $\mathrm{n}=$ 9) $=0.0349$.

Condition 2: Consistency ratio CR $(=0.0349)<0.10$ indicated a reasonable level of consistency in the pairwise comparisons. Therefore, the values obtained satisfy the noted conditions, which denote that the weights obtained are agreeable.

\section{Weighted overlay and suitability map}

In this process, data of selected criteria were overlaid together to generate final suitability classification of the study area for tourism activities. 
All the created thematic layers have been combined in GIS so weighed superposition techniques could have been applied [23]. The suitability of terrains in regards to touristic activities has been identified using weighed superposition techniques stemming from the analytic hierarchy process and the multiple criterion evaluation process. The selected layers of raster have been overlaid by recognizing the values of their cells at the same scale, this providing weight value to the individual criterion while integrating the values of weight cells, conformable to the equation:

\section{Suitability map $=\Sigma$ [criteria map * weight]}

Suitability index $=($ Land cover $* 0.31)+($ Slope $* 0.22)+($ Lithology $* 0.15)+($ Aspect $* 0.11)+($ Proximity to roads $* 0.08)+($ Natural attractiveness sites $* 0.05)+($ Anthropic attractiveness sites $* 0.04)+($ Leisure area $* 0.02)+($ Public facilities $* 0.02)$.

The cells values of each raster layer have been multiplied by their value in weight [24], using the instruments cassette from the program ArcGIS 10.4.

In order to present the final map of the qualification, the variation of the general score was divided into four classes, according to the FAO methodology: highly suitable, moderately suitable, marginally suitable, not suitable.

\section{RESULTS AND DISCUSSIONS}

The total surface of the studied area is that of $16.393,92$ ha, of which $21.91 \%$ are represented by agricultural land (5.60\% arable land, $15.52 \%$ meadows, $0.79 \%$ vine), while the forests cover $71.07 \%$ of the entire area. To be added are building areas occupying $6.06 \%$, sportive and recreation facilities occupying $0.18 \%$ and water streams accounting for $0.60 \%$.

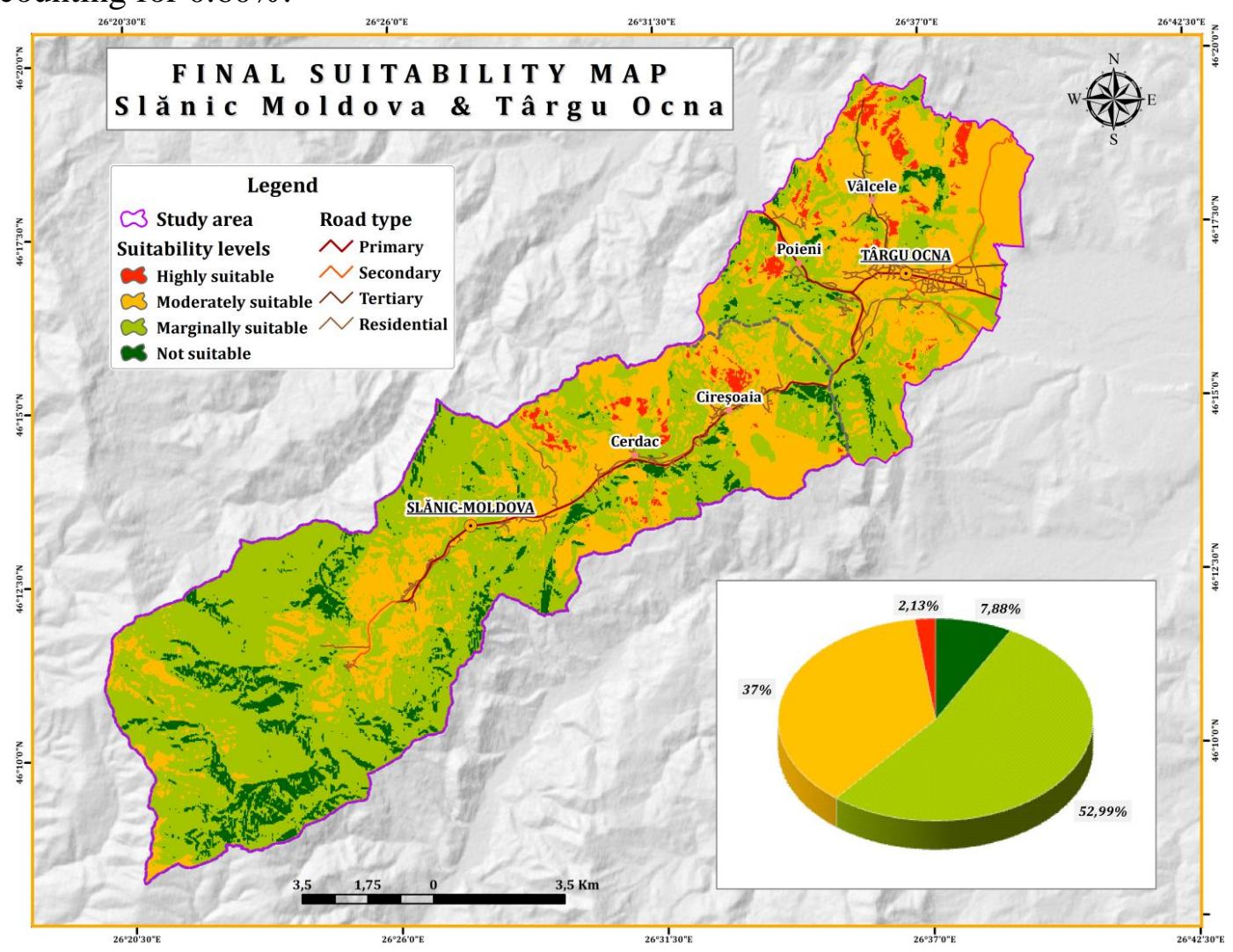

Figure. 4. Final suitability map of the study area 
According to figure 4 it can be deduced that the available terrain consists of $39.13 \%$ of the total surface. These terrains are located mainly in the area of Târgu Ocna resort (62.16\% having moderate and high suitability) and less in the area of Slănic Moldova resort (Table 8). The cause for this is represented by the unfavorable topographical conditions of Slănic Moldova: narrow valley bordered by wooded slopes limiting the extension of the terrains destined for touristic activities.

Table 8. Statistically distribution of area under different suitability categories

\begin{tabular}{ccccc}
\hline \multirow{2}{*}{ Suitability level } & \multicolumn{2}{c}{ Slănic Moldova } & \multicolumn{2}{c}{ Târgu Ocna } \\
\cline { 2 - 5 } & ha & $\mathbf{\%}$ & ha & \% \\
\hline Highly suitable & 128,62 & 1,12 & 225,10 & 4,60 \\
\hline Moderately suitable & 3238,56 & 28,20 & 2816,64 & 57,56 \\
\hline Marginally suitable & 6982,44 & 60,80 & 1693,60 & 34,61 \\
\hline Not suitable & 1134,65 & 9,88 & 158,06 & 3,23 \\
\hline
\end{tabular}

With regards to the analysis of the results and tourism requirements, the typical sites recommended can be summarized based on four classes, as following: highly tourism potential category whic involves the most favorable areas for development (barren lands, gentle slope, south aspect, nearby to attractions and facilities), moderately tourism potential, marginally tourism potential and currently not suitable for tourism, a category which includes areas with restrictive particularities of chosen criteria.

The present study considered three very important aspects that must be taken into account when managing the land: i) the availability of the land and the characteristics of the local natural environment; ii) the existing potential represented by points of tourist attraction and iii3) accessibility in conjunction with the existing infrastructure facilities. Starting from these findings, the present study identified the areas where tourist activities (anthropic arrangements) should be developed in the future, taking into account the current natural and economic particularities.

\section{Validation of the results}

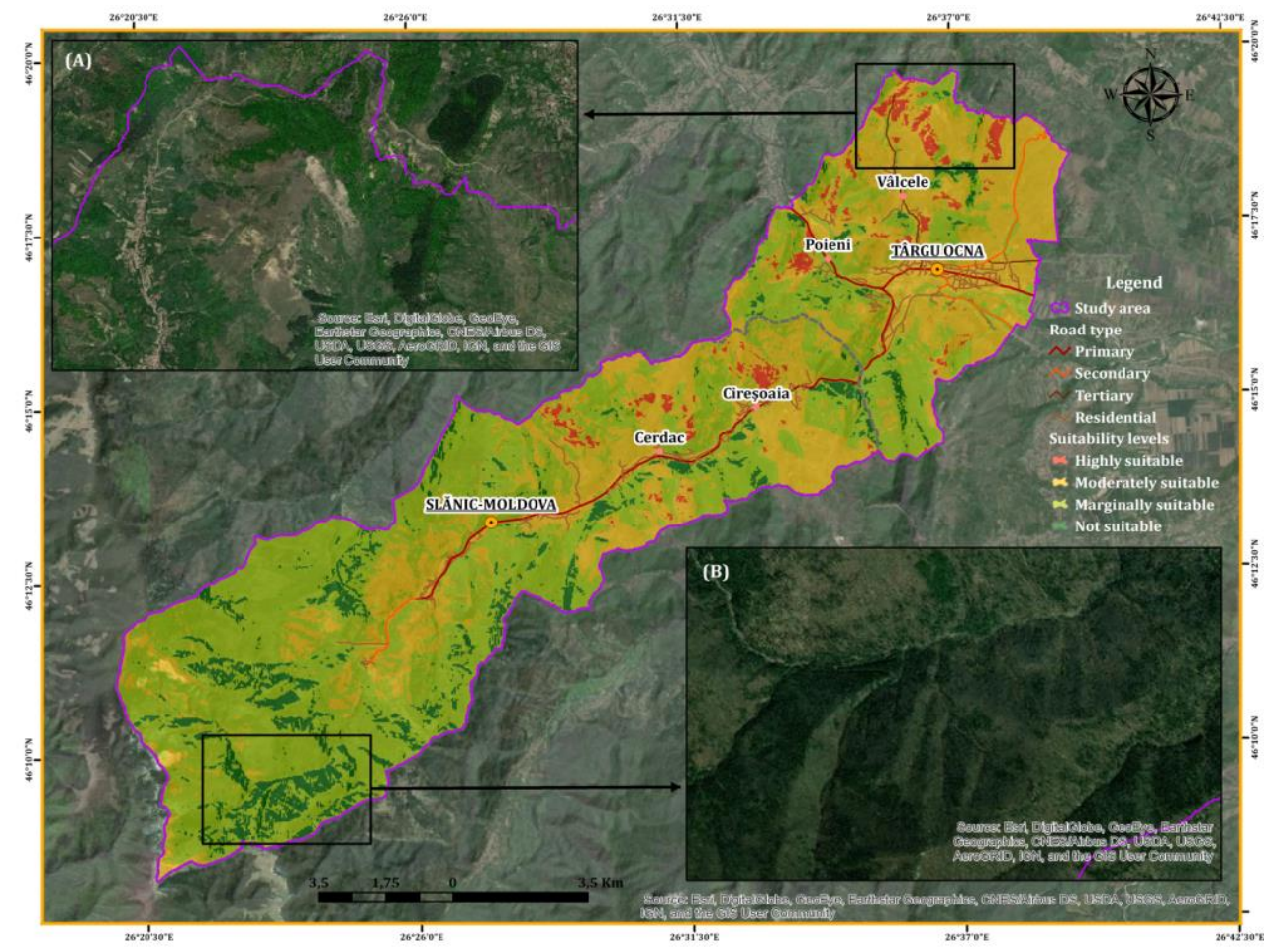

Figure. 5. Example for the validation of the results: highly suitable (A) and no suitable (B) 
In addition to the spatial validation (Figure 5.), there was also a validation of the results according to the overlap of the points represented by the public and tourist infrastructure facilities (nine criterion) over the final map of the suitability. In this regard, I noticed the fact that, out of the total of 231 points representing different facilities, 23 points overlap over areas with marginal probability, and 208 points overlap over areas with moderate probability.

For exemplification two territories have been chosen, A having high suitability and B having no suitability. For the A territory, a series of factors contributed to its suitability: the degree of meadow cover, slopes of $0-15 \%$, orientation preponderantly towards south and south-west, the proximity of the roads and the existence of natural and anthropogenic objectives. For the B territory, the lack of suitability stems from the high degree of forest cover (more than 80\%), high slopes (mainly 7-35\%), orientation towards north, northeast and north-west, lack of communication ways and the degree of isolation.

\section{CONCLUSIONS}

The study proposes a clear image on the availability of terrains characterized by high suitability in the two resorts, through this offering useful information to potential tourism investors who are eager to invest in the area and also to tourists planning their stay/accommodation depending on their own interest (proximity to the sanatorium, saline, water springs, ski trail or other interest points).

The percentage of terrains available for touristic activities $(39,13 \%)$ demonstrates that the studied area holds the potential for further expansion and development while promoting both its particular natural resources (mineral water springs, saline, bioclimate) and its anthropogenic resources (sanatorium, treatment base, monasteries etc).

In the future, the present study can be improved by broadening the scope of the criteria that have an impact on the areas of regional and local territorial planning, in particular the tourism development policies, but especially on the data obtained from the in situ measurements regarding the quality of the therapeutic factors of the area.

\section{REFERENCES}

[1] McHarg, I.L., Design With Nature, Wiley, 1969, New York.

[2] Hopkins, L., Methods for generating land suitability maps: a comparative evaluation. Journal for American, Institute of Planners, 1977, 34 (1), 19-29.

[3] Brail, R.K., Klosterman, R.E., Planning Support Systems, ESRI Press, Redlands, CA, 2001.

[4] Collins, M.G., Steiner, F.R., Rushman, M.J., Land-use suitability analysis in the United States: historical development and promising technological achievements. Environmental Management 28 (5), 2001, 611-621.

[5]. Pereira, J.M.C., Duckstein, L., 1993. A multiple criteria decision-making approach to GISbased land suitability evaluation. 1993, International Journal of Geographical Information Systems 7 (5), 407-424.

[6] Store, R., Kangas, J., Integrating spatial multi-criteria evaluation and expert knowledge for GIS-based habitat suitability modelling. 2001, Landscape and Urban Planning 55 (2), 79-93.

[7] Bonham-Carter, G.F., 1994. Geographic Information Systems for Geoscientists: Modeling with GIS, 1994. Pergamon Press, New York.

[8] Cambell, J.C., Radke, J., Gless, J.T., Whirtshafter, R.M. An application of linear programming and geographic information systems: cropland allocation in antigue, 1992 Environment and Planning A 24, 535-549.

[9] Kalogirou, S. Expert systems and GIS: an application of land suitability evaluation. Computers, 2002. Environment and Urban Systems 26 (2-3), 89-112. 